\title{
「目に優しい3次元ディスプレイ技術」特集号によせて
}

\author{
的場 修 \\ 神戸大学工学部情報知能工学科（干657-8501 兵庫県神戸市灘区六甲台町1-1）

\section{Preface to the Special Issue on Natural Three-Dimensional Display Technology} \\ Osamu MATOBA \\ Department of Computer and Systems Engineering, Kobe University, 1-1 Rokkodai, Nada-ku, Kobe, Hyogo 657-8501
}

(Received November 20, 2006)

映像技術の進歩はすさまじく，ハイビジョン放送は既 に実用化され，2025年にはスーパーハイビジョン放送 $(7680 \times 4320$ 画素)の開始が計画されている. $4096 \times 2160$ 画素の反射型液晶デバイスが既に市販されており，スー パーハイビジョンとともに，今後表示デバイスの高性能 化が見込まれることから, 高精細な画像表示が可能にな る.このように2次元画像に対する映像技術や通信技術は 大きな進歩が見られるが，3次元ディスプレイに対する技 術の進歩は緩やかである，高臨場感については，高画質 化により得られるという方向性もあるが, 真の3次元ディ スプレイによって実現できる臨場感に勝るものはない. これまで様々な手法を用いた 3 次元ディスプレイ装置が開 発されてきたが，それぞれに一長一短があり，どれも広 く普及するにはいたっていない，例えば，ヘッドマウン トディスプレイやパララクスバリアを用いた両眼視差の みに基づく3次元ディスプレイでは，立体感に不自然さが あり，疲労を生じやすいために長時間の利用に適さない と言われている．本特集号では，上記の問題を解決する ためのブレークスルーとなる基盤技術をもつ研究者に執 筆を依頼した。

3次元ディスプレイの魅力的な応用のひとつとして，3 次元映像と人間を繋ぐ，インタラクティブなインタ フェースが考えられる。これまでの人間と機械(コン ピュータ)を繋ぐインタフェースでは, キーボード, マウ ス，ペン入力などを見ても分かるように，人間が機械に 合わせて情報を入力することが求められてきた。これ は，インタフェース技術が未熟な場合には，入力手段を 制限することで, 情報を効率良く入力できるように妥協 した結果である、コンピュータやイメージング機器の高 性能化によって, 人間が機械に合わせるのではなく, 人
間の行う動作や表情，声などをセンシングして機械への入 力に役立てる新しいインタフェースの研究が始まってい る. 古くからある研究としては，音声入力や手書き文字認 識はその一例である。

このようなインタラクティブ可能な自然な3次元インタ フェースを実現するためには，3次元表示系と3次元計測系 の開発が必須である。3次元表示系では，特殊な眼鏡等を 使用することなくリアルタイムで3次元映像を再生する系 の構築が望まれる．現状では，コンピュータグラフィック スなどにより2次元ディスプレイにおいて3次元情報として 表現している．例えば，インターネットショッピングや住 宅購入などコンピュータ上で3次元空間の情報をインタラ クティブに見ることが可能である. しかしながら，多くの 場合, 通常の2次元ディスプレイが使用されている. した がって，2次元ディスプレイにより提示された 3 次元情報の 構造を把握するためには, 頭の中で3次元像を構築する必 要がある.このことは, 3次元情報に不慣れな人の創作活 動を阻害する大きな要因となっている。一方，人がものを 創造する際に，何を見て，何を考え，どのような動作で行 うのかを知ることは，次世代のものづくり支援や芸術等の 創作活動に大きく役立つものと考えられる．自然な3次元 ディスプレイが実現できれば，大きな可能性が見込まれ る。また，3次元計測系では，より自然で自由な環境下 で，人や対象物を3次元的に計測し，リアルタイムで人 物, 動作, 行動を認識するシステムの構築が必要となる. この2つの系を組み合わせることで，自然な3次元インタ フェースが構築され，映像文化だけではなく，人間の創造 活動において革新的なシステムを提供することが期待でき る. 本特集号が，自然な3次元表示系を実現するためのブ レークスルーの一翼を担うことになれば幸いである. 